\title{
Corinth and Olympia
}

\author{
"If all the year were playing holidays, \\ To sport would be as tedious as to work;"
}

Shakespeare, King Henry IV Part I

Summer heat. Sip the iced drink. Shift the sunshade. Switch on. Cricket? Rugger? It's all the same Test Match defeat. Tennis? Where on earth is Britain's return on its enormous coaching investment? Is the eternal promise of comers, who never arrive, all we get for our $£ 0.45$ strawberry at Wimbledon? Athletics? Fading heroes flail alike against clocks biological and electronic. Where's our depth in field events? How many women are world top ten ranked compared with a decade ago? Another coaching: failure or what? Switch off and scan the journals.

As we give up the unequal struggle against the small screen's glare, another midsummer nightmare flickers into the vacant mind - the Dubin Inquiry. The Ben Johnson revelations cut deeply into one event in one sport, but surely taint the rest in passing. Top athletes, coaches and sports doctors alike stand condemned. Any optimist pretending that his country is dopeless must surely now remove his blinkers, whatever the whitewash of other inquiries stifled by the fear of libel. There has been too much governing body ambivalence, even in Britain, towards the support of doctors who speak out against doping. Administrators too often emulate the ostrich and hope drugs will disappear. The constant upping of Olympic entry standards to anabolic levels means that sport officials have de facto set the pace of doping.

Is the Corinthian ideal an illusion in top sport? With the prostitution of the Olympic ideal and the spurious redefinition of 'amateur' - as, in effect, those whose unlimited earnings must be handled by their governing bodies so that they can also take their cut - commercialism may have made the final cut from Corinthian values.

'Sports Medicine' is central to these considerations. We have to look at different levels of sports medicine services. Where do elite and mass provision overlap? Do we owe a common basic level of universal care upon which governing bodies must themselves commission their own specific extras and if so, at whose expense? A consequence of governmental nonrecognition of sports medicine over the years is that there are simply not enough specialist resources available to satisfy the basic needs of every sport. Are there no medical responsibilities incumbent upon governments who sponsor a policy of 'Sport for All'?

The dilemma in Britain is that we are years behind the rest of Europe in the recognition of, and hence provision for, sports medicine and there is yet another Health Service crisis. Distinction is made by today's hospital managers 'between sports medicine and NHS commitments' and criteria are laid down that services are to be 'financially viable'. Does this mean that our few sports clinics will be squeezed out of existence unless some 'sponsor' supports them? This undermines the development of expertise which is accumulated by those few clinicians whose reputations attract a wide range of clinical and geographical referrals. Few would be confident, with even BASM's courses less than fifteen years old, that there is enough skill yet to delegate all sports medical care to each doctor or hospital unit though that is surely an eventual aim.

The need for a government recognized national centre for sports medicine is becoming desperate for several reasons, which include:

(1) The burden of sports injuries to the NHS, sickness benefit payments and industry: any improvement in care would be economical. 
(2) More training and education is needed to achieve this - but cannot be profitable in the foreseeable future. The Sports Council recognizes this by its limited funding of the BASM Education Officer.

(3) Advertising by paramedicals and the unqualified is rampant in sports medicine. Only the orthodox are forbidden even to announce themselves! The lack of clinical quality control is evident in the rash of self-advertisements which fill sports magazines and changing rooms.

If 'sports medicine' is to avoid becoming the Pandora's Box of medicine, it is essential to counterbalance quackery with the responsible study and development of safe and reputable sports medicine practice. In all other branches of medicine this means academic, institutional and governmental recognition - why not in sports medicine?

(4) Sports medicine embraces 'exercise and health', a government policy which surely needs to be medically underpinned.

(5) Most cogently, from sport itself comes the pressure for scrutiny and responsible care. There are many precedents, from doping to cavalier joint injection, of medical abuse at the behest or connivance of sport managers and senior coaches. The danger is that the team doctor becomes the meat in the sandwich between the manager using sports medicine as the short cut to performance and the collusion of coaches with athletes in unbridled pursuit of unlimited rewards.

Increasing commercialization of 'amateur' sport and 'privatization' of our Health Service can only increase these pressures. At risk is loss of control of medical standards in sport.

Perhaps Olympia should look once more to Corinth before public disillusion questions its claim to resources. 